\title{
Gaudium et spes a kulturní paradigma 21. století Helmut Renöckl
}

Vznik konstituce $O$ církvi v dnešním světě - Gaudium et spes ${ }^{1}$ byl velmi napínavý. V koncilovém schématu, připraveném kurií, měla témata pozdější konstituce $O$ církvi v dnešním světě jen marginální význam. Na základě iniciativy koncilních biskupů a při zapojení odborníků $\mathrm{z}$ celého světa a rovněž v ekumenické spolupráci rostl text $\mathrm{z}$ mnoha návrhů, doplňků a změn a až do závěrečného schvalování nebylo jisté, zda a s jakými stanovisky bude přijat. Výsledek byl působivý: Konstituce, která má plnou autoritu koncilu, byla přijata 2111 hlasy pro, 251 proti a 7 neplatnými hlasy. Celosvětově byl ohlas na tuto konstituci v církvi i mimo ni velmi silný a - nehledě na známé skupiny rozhodných odpůrců - velmi pozitivní. V rozsáhlé shodě je konstituce Gaudium et spes ${ }^{2}$ řazena $\mathrm{k}$ nejdůležitějším a dlouhodobě působícím výsledkům koncilu. $\mathrm{V}$ tomto článku je představeno kulturní paradigma vyjádřené v Gaudium et spes a také nejdůležitější změny kulturního paradigmatu během 50 let po koncilu, vždy s ohledem na vztahy mezi „církvi“" a „světem“, přičemž hledisko autora je silně ovlivněno hlavními oblastmi jeho aktuální činnosti - etikou v oborech prŕrodních věd a techniky, medicíny a hospodářství.

\section{Rozdílné chápání „kultury“ a „paradigmatu“}

Obecně rozšiřrené chápání kultury je selektivní. Obsah pojmu kultura v novinách a časopisech či kulturních pořadech $\mathrm{v}$ rozhlasu a televizi se zpravidla do značné míry omezuje na oblast hudby, divadla, literatury, umění, múzické sféry. To jsou velmi důležité oblasti, avšak přece jen jsou pouze určitými úseky rozsáhlého chápání kultury, ze kterého konstituce zcela výslovně vychází. ${ }^{3}$ Kultura skutečně zahrnuje celou sféru lidských výtvorů, které člověk vytvořil a dále utvárí. Kromě umělecké a múzické oblasti je zde třeba uvést všechny podstatné oblasti lidského života, jako je kultura rodiny, kultura všedního dne, pracovní kultura, podnikatelská kultura, kultura zemědělství, kultura krajiny, stavební kultura, politická kultura atd. ${ }^{4} \mathrm{~A}$ je třeba mít obzvlášt na paměti, že se kultura vyvijí dějinně vždy v plurálu, což pastorální konstituce výslovně zdůraz-

1 Latinsko-německé vydání (oficiální překlad německé biskupské konference), vytištěno ve svazcích dokumentů Heinrich S. BRECHTER a kol. (ed.), Das Zweite Vatikanische Konzil (doplňující svazky k Lexikon für Theologie und Kirche, 2. vydání), díl III, Freiburg im Breisgau, 1968, s. 241-592; Guilherme BARAUNA (ed.), Die Kirche in der Welt von heute. Untersuchungen und Kommentare zur Pastoralkonstitution Gaudium et Spes des II. Vatikanischen Konzils, Salzburg, 1967; Bernd Jochen HILBERATH - Peter HÜNERMANN (ed.), Herders Theologischer Kommentar zum Zweiten Vatikanischen Konzil, 5 svazků, Freiburg, 2004/5; Hans-Joachim SANDER, Theologischer Kommentar zur Pastoralkonstitution über die Kirche in der Welt von heute, sv. 4, Freiburg, 2005, s. 581-886.

2 Dále pouze GS a číslo př́slušného oddílu.

Viz GS 53

4 Viz Friedrich JAEGER - Hans JOAS (ed.), Europa im Spiegel der Kulturwissenschaften, Baden-Baden, 2008; Christoph MANDRY, Europa als Wertegemeinschaft, Baden-Baden, 2009. 
ňuje. ${ }^{5}$ Známe různé náboženské kultury, kultury národů a kultury epoch, jako je kultura antická, stř̌edověká a novověká. Toto široké chápání kultury vychází z antropologických základních předpokladů: My lidé jsme na jedné straně vázáni přírodními souvislostmi, na druhé straně jsme díky svým duševním schopnostem otevřené bytosti, které mohou vymýšlet a uskutečňovat nové věci, komunikovat a spolupracovat mezi sebou navzájem a předávat lidské výtvory z generace na generaci, z epochy na epochu. Lidská přirozenost tudíž není něco uzavřeného a statického, $\mathrm{k}$ lidské přirozenosti patří individuální a společenská kreativita stejně jako dějinnost; my lidé jsme schopni vytvářet kulturu a také kulturu potřebujeme. ${ }^{6}$

Rovněž termín „paradigma“ je potřeba objasnit. V současné době se používá v nejrůznějších oblastech života a věd: Mluví se o změně paradigmatu ve filosofii, literatuře, umění, fyzice, psychologii, v politice a v hospodářství... „Paradigma“ může znamenat velmi různé věci: $\mathrm{V}$ platónské tradici byla paradigmata věčnými, neměnnými vzory z duchovního „nadsvěta“, které umožňují smysluplné vnímání pozemských skutečností. Zcela jiné je moderní chápání. Např. podle Ludwiga Wittgensteina jsou paradigmata vzory, podle nichž se porovnávají zkušenosti. Zvláště významný byl pro šírení pojmu "paradigma“ Thomas $\mathrm{S}$. Kuhn, ${ }^{7}$ který chápe paradigmata jako základní figury ke strukturalizaci dějinně proměnné rozmanitosti v poznání a jednání. Kuhn sám se postupně vzdával striktní definice svého pojmu „paradigma“. Paradigmata jsou někdy považována spíše za symbolické než pojmové základní předpoklady a hlediska, soubory axiomů a hypotéz; jsou považována spíše za „vize“. Paradigmata akcentují, stimulují, orientují a integrují vnímání, myšlení a jednání. Pro naši tematiku se doporučuje spíše zaměření na paradigmata dějinných epoch, konkrétně na přednovověké, novověké a dosud ještě nezřetelné postnovověké paradigma. Před novověkem platilo vše, co se dělo, za přirozené a Bohem chtěné, a člověk se do tohoto řádu musel začlenit. K tomu patřily pro velkou většinu lidí omezené životní poměry, utrpení, nouze a často př̀edčasná smrt. Vůdčí představou byl „řád“, který byl nezpochybnitelný, a př́ísně „hierarchická“ pyramida moci. Zcela jinak tomu bylo v novověku: Vůdčí představou zde bylo „osvobození“. To interpretovalo vše, co se dělo, už nikoliv jako něco předem určeného, co je třeba přijmout, ale jako výchozí situaci pro lidské utváření. Především metodami prrírodních věd se aktivně zkoumaly všechny danosti, aby jimi mohlo být disponováno, aby se přetvořily směrem $\mathrm{k}$ dalekosáhlému překročení hranic a osvobození od nouze, utrpení a cizího ovládání shora. ${ }^{8}$

\section{2. Úspěchy novověkého programu a církevní resentiment}

$\mathrm{Z}$ dnešního hlediska je třeba ocenit ohromné úspěchy novověkého programu; pomysleme jen na zdvojnásobenou průměrnou délku lidského života, na možnosti vzdělávání a spolurozhodování, blahobyt, zdravotnické a sociální systémy pro široké vrstvy obyvatel. Konkrétní průběh změny paradigmatu od středověku k novověku však byl plný konfliktů, chaotický a krvavý; nebyli jen vítězové modernizace, ale také její poražení. Církev a teologové - nehledě na významné výjimky

5 GS 53.

6 Viz stále doporučeníhodný názorný přehled v Heinrich ROMBACH, Leben des Geistes. Ein Buch der Bilder zur Fundamentalgeschichte der Menschheit, Freiburg im Breisgau: Herder, 1977.

7 Srov. Thomas S. KUHN, Die Struktur wissenschaftlicher Revolutionen, Frankfurt/M., 1979. V tomto díle chápe Kuhn (srov. s. 160n) paradigma jako poučky, soubor hypotéz nebo teoretické koncepty, které považují určité vědecké směrnice nebo skupiny vědců za platné.

8 Viz rozsáhlou, intenzivně a kontroverzně diskutovanou duchovně historickou studii k novověku Hans BLUMENBERG, Die Legitimität der Neuzeit, obnovené vydání Frankfurt, 1996 (stw 12168). K sociálním dějinám obecně viz Wolfram FISCHER (ed.), Handbuch der europäischen Wirtschafts- und Sozialgeschichte, zvláště svazek 5, Stuttgart, 1985. 
jako např. Nicolaus Cusanus / Mikuláš Kusánský - zvládali přelom středověku a novověku špatně. Nař́ikali na tě̌̌ké ztráty stř̌edověkých pozic moci, majetku a vlivu, na šok rozštěpení víry, náboženské války, traumatizující zkušenosti chaosu „francouzské revoluce“. První konsolidace rozvrácené katolické církve se uskutečnila Tridentským koncilem, ovšem výrazně defenzivním, vymezujícím se způsobem. Nezdařila se inkulturace biblické inspirace do novověkého světa, došlo $k$ fatálnímu konfrontačnímu a opozičnímu vývoji mezi vírou a osvícenským vědomím, vědou a teologií, církví a společností, vyhrocenému ještě „kulturním bojem“v 19. a na začátku 20. století.

Ohromné sociokulturní převraty způsobily v 19. století „průmyslovou revoluci“, stimulovanou novověkým paradigmatem. Církevními autoritami dlouho nebyla pochopena a nebylo na ni včas a přiměřeně reagováno. ${ }^{9} \mathrm{~V}$ průmyslových odvětvích, velmi důležitých oblastech moderní společnosti, byla a je církev zřejmě sociálně a charitativně přítomna, avšak pastoračně jen slabě a ještě méně v oblasti utváření společnosti. Defenzivní a na předmoderním paradigmatu lpící katolická církev zesílila tuto profilaci na I. vatikánském koncilu a v mnoha papežských encyklikách té doby, nejzřetelněji v Sylabu. „Modernismus“ byl ostř̌e odmítán. V emancipačním programu novověku byla spatřována „prométheovská vzpoura proti Bohu a církvi“, svoboda byla tak jako tak podezřelá, svoboda náboženství byla striktně odmítána, svoboda svědomí stigmatizována jako „šílenstvi“ (deliramentum), Řehoř XVI. polemizoval proti preventivnímu očkování, které by „chtělo zadržet trestající ruku Boží. Energicky prosazovanou neoscholastickou filosofií a teologií jako závaznou církevní doktrínou, zostřeným centralistickým církevním právem a celosvětově uniformní latinskou liturgií byla snaha zajistit stabilní katolickou Societas perfecta, a to v ostrém vymezení se vůči „bloudícímu světu bez spásy“, ale také vůči jiným křestanským konfesím a jiným náboženstvím..$^{10}$

Nesmíme však přehlédnout, že tato katolická církev se svou jasně uspořádanou disciplínou, doktrínou a liturgií byla velmi působivá a v tehdejších mnohých společenských a ekonomických zvratech, válkách, vykořenění a ztrátách autorit poskytovala znejistěným lidem oporu a bezpečí. Ovšem tato nehistoricky ustrnulá konstrukce vedla stále více $\mathrm{k}$ vnitřním napětím a k dalekosáhlé izolaci vůči dynamicky probíhajícímu společenskému vývoji „ve světě“.

\section{Po dlouhém ochromujícím odmítání respekt vůči novověkému paradigmatu na II. vatikánském koncilu, zvláště v Gaudium et spes}

Teprve na tomto pozadí je nutno ocenit prorockou postavu papeže Jana XXIII. a jeho svolání II. vatikánského koncilu, čímž došlo skutečně k novému historickému nasměrování. Papež Jan XXIII. byl na základě své hluboké víry prost strachu ve svých zásadních postojích a byl plný naděje. Jako vzdělaný historik věděl o zásadním významu dějinnosti a dějin, znal a oceňoval východní křestanské církve, islám, židovství a jejich kultury. Koncil pak byl působivým celkovým úsilím světové církve a dosvědčoval na mnoha důležitých místech vytvořených dokumentů omezenost

9 LEV XIII., Rerum novarum (1891); Karl MARX, Das Kommunistische Manifest (1847/48). Ke křestanskému sociálnímu učení viz Johannes MESSNER, Die soziale Frage, 7. vyd., Innsbruck, 1964; Oswald von NELL-BREUNING, Wie sozial ist die Kirche? Leistung und Versagen der katholischen Soziallehre, Düsseldorf, 1972; Arno ANZENBACHER, Christliche Sozialethik. Einführung und Prinzipien, Paderborn, 1998, s. 41-177; Marie-Dominique CHENU, Kirchliche Soziallehre im Wandel. Das Ringen der Kirche um das Verständnis der gesellschaftlichen Wirklichkeit, Fribourg - Luzern, 1991.

10 Dalekosáhlé odmítání novověkého paradigmatu církevním vedením je dnes již těžko pochopitelné. Doporučuje se proto přečíst si všechny dokumenty církevního učení té doby (papežů Řehoře XVI., Pia IX., Lva XIII.) v Enchiridion symbolorum, definitionum et declarationum de rebus fidei et morum, zde je použito 33. vydání, ed. Heinrich DENZINGER - Adolf SCHÖNMETZER, Freiburg im Breisgau: Herder, 1965, s. 548-631. 
a antimoderní uzavření se církve a teologie. Tímto koncilem vstoupila katolická církev odvážně do respektujícího dialogu s moderním světem.

Obzvlášt zřejmé je to v celé pastorální konstituci Gaudium et spes. Její ústř̌ední výpovědi o kultuře zř̌etelně dokládají zásadní změnu postoje nejvy̌šší autority učení církve vůči modernímu světu: Církev se cítí být „,skutečně pevně spjatá "11 $s$ celým lidstvem a jeho dějinami ve všech radostných i skličujících aspektech. Chce zkoumat „znamení doby a vykládat je ve světle evangelia“.12 Svoboda člověka a lidské úsilí o poznání jsou výslovně uznávány a ctěny: „Člověk se však může přiklonit $\mathrm{k}$ dobru jen svobodně. Tuto svobodu naši současníci vysoce oceňují a vášnivě o ni usilují, a to je správné. " ${ }^{13}$ Zvláště naléhavě a působivě je vyzdvižena jedinečná důstojnost lidského svědomí: „Svědomí je nejtajnější střed a svatyně člověka, v níž je sám s Bohem, jehož hlas mu zaznívá v nitru. Prostř̌ednictvím svědomí si podivuhodným způsobem uvědomuje zákon, který splňuje milováním Boha a bližního. Věrnost svědomí spojuje křestany s ostatními lidmi při hledání pravdy a při pravdivém řešení mnoha mravních problémů, které vyvstávají v životě jednotlivců a ve

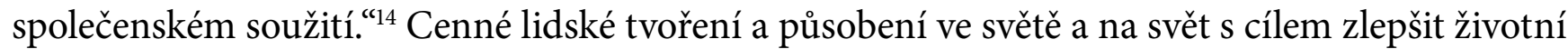

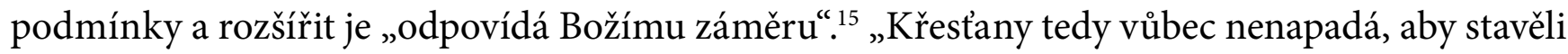
proti sobě díla, která vytvořili lidé svým důvtipem a silou, a Boží moc, jako by rozumný tvor

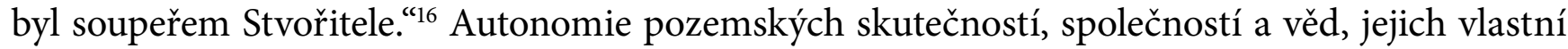
zákonitosti a hodnoty jsou výslovně uznávány a je vyjádřeno politování nad tím, že kdysi nebyla ani mezi křestany respektována legitimní autonomie věd..$^{17}$

Církev se už nepovažuje za „majitelku velké pravdy“, nemůže a nechce mnoho konkrétních otázek života rozhodovat shora, ale je připravena respektovat odborné vědomosti v jednotlivých odborných oblastech. Výslovně se požaduje oprávněný pluralismus, na který je třeba dbát v mnoha věcných oblastech, zvláště na poli politiky. „Mnohdy je už křestanský pohled na skutečnost přivede $\mathrm{k}$ určitému řešení $\mathrm{v}$ konkrétní situaci. Jiní věřící však, jak se často a oprávněně stává, budou s nemenší upřímností o téže věci soudit jinak. (...musí mít na paměti...), že v takových případech nikomu není dovoleno dovolávat se církevní autority výlučně ve prospěch svého názoru. At̉ se však vždycky snaží objasnit vše upřímným rozhovorem, při němž zachovají vzájemnou lásku a dají se vést především starostí o obecné blaho. ${ }^{\text {“18 }}$

Již těchto několik př́kladů vytváří jasný kontrast ke shora uvedeným pozicím I. vatikánského koncilu, Syllabu a četným odsouzením „modernismu“. Tímto osvobozením se od anti-novověkého postoje a ochotou k respektujícímu dialogu se současným světem a jeho kulturou byly církví přijaty podstatné prvky paradigmatu novověku. Výčitka tradicionalistických skupin, že se tím koncil nekriticky přizpůsobil duchu doby, jistě není na místě. Dokazuje to studium historie vzniku textu, porad, návrhů textu a pozdější hlasování o změnách. ${ }^{19}$ Mnoho biskupů, teologů, pastoračních pracovníků a mnoho veřících křestanů usilovalo o překonání uzavřenosti katolické církve, neslučitelné s jejím posláním, vưči moderním skutečnostem života. Avšak zatímco jedni

11 Srov. GS 1, 2, 3.

12 Srov. GS 4, 11.

13 GS 17.

14 GS 16.

15 GS 33,34 .

16 GS 34.

17 Srov. GS 36.

18 GS 43.

19 Srov. např. výše (pozn. 4) s. 242-279, dokumentaci prof. Charlese Moellera Löwen-Rom, který se od začátku velkou měrou podílel na vypracování pastorální konstituce. 
spoléhali na sebezajištění církve defenzivní uzavřeností a autoritářskými strukturami, snažili se ti druzí již dávno před koncilem a pak také zodpovědní lidé na koncilu o ressourcement, o inspiraci a rozšíření horizontu především $\mathrm{z}$ biblických pramenů. Na mnoha teologických fakultách vedly prohloubené exegetické a biblicko-teologické výzkumy a poznatky k odpovídající nové orientaci také v nových oborech systematické teologie. Bylo jasné, že biblické zjevení představuje dějiny zjevení, které pokračují dějinami působení biblického poselství. Seriózní výklad potřebuje hermeneutiku, úsilí o co nejlepší chápání toho, co chtěly texty v době svého vzniku sdělit svým adresátům a co to má přes „př́kopy dějin“ sdělit dnešním adresátům za zcela jiných podmínek. Adolf Darlap, blízký spolupracovník Karla Rahnera, formuloval jako souhrn biblického poselství pointu: „Nasměrování $\mathrm{v}$ dějinách!“" ${ }^{20}$ Přinejmenším stejně důležitá jako teologické úsilí byla také hnutí ve farnostech a církevních společenstvích vznikající již v desetiletích před koncilem. Byla to např. silná hnutí v Rakousku, Německu a ve Francii volající po národní liturgii, v biblických kroužcích se pěstovala biblická spiritualita, zřetelně vzrůstala aktivní účast věřících na životě církve.

Obraz člověka a světa v pastorální konstituci není v žádném př́ípadě levné kopírování ducha doby, ale je veskrze biblický. Člověk je představován jako Boží obraz, jako spolutvưrce světa, který v souladu $s$ výpovědí listu Rímanům - je uskutečňovaným stvořením a „pracuje k porodu“ ( $\mathrm{R} 8$, zvláště 8,22n). Poukazuje se jasně na ambivalenci svobody, na omyly a vinu, na nevyhnutelné spojení s božským Stvořitelem, Vykupitelem, tím, kdo vše završuje v dokonalosti; v mnoha aspektech jsme zde stále upozorňováni na lásku $\mathrm{k}$ bližním a na obecné dobro jako nejniternější zaměření křestanské praxe. $Z$ dnešního pohledu bychom mohli poznamenat, že se občas moderní vývoj hodnotí př́liš optimisticky a že není pojednáno o otevřených otázkách a problémech „na konci novověku“ (viz dále bod 4). Avšak jestliže církev svou vinou zahájila dialog s modernou až tak pozdě, pak nechce tento dialog zahájit seznamem kritických poznámek. Důležité je každopádně teologické vysvětlení: Církev nesmí být považována za uzavřenou pevnost, ale za „Boží lid putující", odkázaný na dialog se světem. Křestané mají působit jako sůl a kvas, přičemž se mají promísit $s$ „moukou“ lidství a dějinami světa. Když se „kvas“ a „mouka“ uzavřou do sebe, protože se chtějí vyhnout výzvám a obtížím dějin, pak nesplní svou úlohu.

\section{Pokoncilní vývoj v církvi, nové otázky na konci novověku}

Zahájení II. vatikánského koncilu znamenalo pro katolickou církev po dlouhém ustrnutí mohutný skok vpřed, ale také ohromnou výzvu, pro mnohé to bylo dokonce př́liš. Vnitrocírkevně je třeba nejdřive připomenout důležité „plody koncilu“, jako je např. obnovená liturgie, která umožňuje srozumitelné spoluslavení věŕících, zintenzivnila se spolupráce a spoluzodpovědnost ve farnostech, katecheze se přibližila životu a koncipovala se tak, aby odpovídala věku, u rádových společenství se upustilo od anachronických předpisů.

Avšak rozhodující osobnosti v římských ústředních pozicích a také některé skupiny v základně projevovaly značný odpor proti reformám, a tak došlo k restaurativním opatřením $\mathrm{s}$ těžkými následky (Rakousko v tomto ohledu udělalo velmi bolestné zkušenosti s dramatickými škodami pro církev). Vídeňský světící biskup DDr. Helmut Krätzl, který byl jako mladý kněz koncilním

20 Srov. k tomu Adolf DARLAP, Fundamentale Theologie der Heilsgeschichte, in: Mysterium Salutis. Grundriss heilsgeschichtlicher Dogmatik: Die Grundlagen heilsgeschichtlicher Dogmatik, sv. 1, ed. Johannes FEINER - Magnus LÖHRER, Einsiedeln, 1965, s. 3-159. 
stenografem, a tak také jedním z posledních žijících současníků koncilu, to trefně vyjádřil v názvu své knihy o pokoncilním vývoji: Im Sprung gehemmt („Bržděni ve skoku“). ${ }^{21}$ To se týká jak pastorace, tak také především započatého dialogu církve se světem a př́tomnosti církve a teologie $\mathrm{v}$ rozhodujících oblastech dnešního života. Mnohým oboustranným nedorozuměním a nepřátelstvím bylo zabráněno, avšak dosud se nepodařila - $s$ výjimkou několika počinů - podstatná inkulturace biblické inspirace do moderních oblastí a vzorů života, určovaných vědou, technikou a hospodářstvím. ${ }^{22}$ Podstatné důvody tohoto vývoje spočívají zřejmě v dlouhodobém odmítání novověkého paradigmatu katolickými autoritami a ve $\mathrm{z}$ toho vyplývajícím protichůdném vývoji církve a moderního světa, který není možno zpracovat $\mathrm{v}$ několika desetiletích.

Společenský vývoj v 50 letech po koncilu razantně pokračoval. Množí se odkazy na začínající změnu paradigmatu. Epochální paradigmata se vyvíjejí ze změněných situací doby a z nových výzev. Stanoví se nové akcenty, aby se stimulovala, orientovala a spojovala odpovídající úsilí. Epochální programy pak ztrácejí se stupněm jejich realizace na své mobilizační a orientační síle, stále zřetelnějšími se stávají otevřené záležitosti a otázky, problémy důsledků epochálního paradigmatu a nové otázky a výzvy.

V současné době dochází - podobně převratně jako při „průmyslové revoluci“ v 19. století - $\mathrm{k}$ celosvětové, sociokulturní významné přeměně - ke „globalizaci“. Spouštěči jsou zde opět nové technologie, tentokrát elektronická informační a komunikační technika a life-sciences. Opět se při tom nevratně mění rozvinuté a zaběhlé hospodářské a společenské struktury, ale také vědomí a vzorce chování. Významné výzkumné a hospodářské procesy probíhají nyní globálně. Rychlá celosvětová mobilita informací, zboží, služeb a kapitálu umožňuje - a uplatnění vývoje a náklady na zařízení vyžadují - globální propojení a nadnárodní trhy. Ekonomicky a politicky se tak celosvětově znovu zamíchaly karty a šance, zátěže, rozhodující centra a pracovní místa se po celém světě nově rozdělují. Tyto procesy doprovází mohutné „stěhování národü“, dobrovolná mobilita a nedobrovolná migrace. Celá průmyslová odvětví s milióny pracovních míst byla přesunuta $\mathrm{z}$ evropských zemí s vysokými mzdovými, sociálními a ekologickými standardy do oblastí s nízkými náklady právě na základě těchto nízkých standardů.

"Globalizace“ se většinou vztahuje jen k ekonomickým převratným změnám. Silná „globalizace“ se však uskutečňuje i socio-kulturně a mentálně: Především elektronickými médii dochází $\mathrm{k}$ intenzivní difuzi i infuzi informací, obrazů, světonázorů a vzorců chování z celého světa. To vede $\mathrm{k}$ silně změněným obsahům a strukturám ve vědomí člověka, ke změněným hlediskům a vzorcům chování. Ani vně, ani uvnitř už neexistují žádné uzavřené „světy“, identity a kultury. Již při „průmyslové revoluci“ v 19. století se ukázalo, že nedostatečné zaměření technicko-ekonomické dynamiky na humánní hodnoty a na obecné dobro vede uvnitř společnosti i mezinárodně k nábojům konfliktů s extrémně destruktivními důsledky, dokonce i ke světovým válkám. ${ }^{23}$

V Evropě byl po nesmírně bolestných zkušenostech obou velkých válek s milióny mrtvých, tě-

21 Helmut KRÄTZL, Im Sprung gehemmt. Was mir nach dem Konzil noch alles fehlt, Mödling, 1998.

22 Pozitivní př́íklady zdařilé inkulturace biblicko-křestanské inspirace: 1. křestanská antika - tehdy se podařila změna kultury osobního a veřejného života žitou křestanskou nadějí a láskou k bližním; 2 . středověk - v chaotických poměrech po pádu římsko-helenistické říše a její kultury a stěhování národů došlo k ohromnému vývoji ve vzdělání a kultivaci germánských a slovanských kmenů; 3. tradič ní venkovská zemědělská kultura - práce, všední dny i svátky byly prožívány ve vzájemném působení křestanských symbolů, obřadů a rytmů.

23 Srov. Helmut RENÖCKL, Zukunftsregion (Mittel-) in: Deutsch ohne Grenzen (Němčina bez hranic), Gesellschaftswissenschaften, ed. Alena JAKLOVÁ - Anja E. FERENCE, Brno: Tschech. Germanistenverband, 2015, s. 27-49. 
lesných i duševních invalidů, vysídlených a vykořeněných lidí vytvořen společenský a hospodářský model svobodného právního státu s (eko-)sociálním tržním hospodářstvím. ${ }^{24}$ Osobnosti $s$ křestanským přesvědčením a politickým umem zde hrály rozhodující roli. Nyní jsou evropské modely svobodného právního státu se sociálně moderovaným tržním hospodářstvím v globální konkurenci společenských a hospodářských modelů. Eticky je $\mathrm{v}$ každém př́ípadě nutné trvat na tom, že při každém osobním i společenském rozhodování a utváření musí být brán zřetel na důsledky. Elektronická informační a komunikační technika, life-sciences a globalizované hospodářství jsou špičkovými výkony novověkého programu ovládání př́rody a utváření světa. Tím byla protržena „hráz“ a síly hýbající světem, řízení života, dědičnost, vzduch, moře a klima se dostaly do dispozice lidí, ekonomiky a průmyslu. ${ }^{25}$

Z ekonomického, politického, filosofického a teologického hlediska je bráno př́liš málo v potaz, jak zásadně se tím změnila naše situace. Rapidní nárůst lidských znalostí a možností zasahovat způsobil zhroucení dosud určujícího a ochranného řádu přírody a na něj navazujících kultur a etik. Toto překročení hranic s sebou však nepřináší - jak doufal novověk - bezprostřední pokrok a svobodu. Nejdříve jsme se ocitli v radikální ztrátě orientace. Vlivem naší extenzivně a intenzivně „světem hýbající“ eficience už nemůžeme vycházet z toho, že „příroda“ je zde jako spolehlivý regulační rámec a stabilní základ našeho života a jednání. Vlivem možnosti disponovat „světem hýbajícími“ eficiencemi spočívá spíše zodpovědnost za ekosystémovou rovnováhu a za budoucí kulturu života v odpovídající míře na lidských bedrech. Kdo by si dovolil tvrdit, že jsme toho již jak osobně, tak společensky schopni?

Vzhledem $\mathrm{k}$ této převratné zodpovědnosti „na konci novověku“ se ukazují regresivní tendence. Místo prométheovského emancipačního elánu a ochoty utvářet novou humánní společnost, jak tomu bylo na začátku a ve vrcholné fázi novověku, se nyní interpretují lidské možnosti a s nimi spojená zodpovědnost stále více jako velmi malé a rozhodující vliv se přisuzuje přírodnímu řízení („sobecké“ geny, neuronové a instinktivní řízení jednání, případně survival of the fittest) nebo anonymním mechanismům (např. „síly trhu“, „zákonitosti kapitálu“). Dalším „odlehčením“ je postmoderní vzdání se „velkých příběhư“ a zodpovědného rozhodování proklamací dalekosáhlé „rovnocennosti“ i nejrůznějších postojů. Postmoderna je chudá na naději a slabá v orientaci.

Naproti tomu je třeba upozornit na to, že už se ve sféře lidských vymožeností, včetně vědeckých, technických a ekonomických dominujících oblastí, nelze spoléhat ani vymlouvat na prírodní ríizení a věcné mechanismy. Naším úkolem je spíše, abychom se při zacházení s prrírodním programováním věcnými zákonitostmi sami ř́dili, učili se vzájemnému lidskému soužití a spolupráci na tvoření, přiměřeným proporcím a prioritám, ohledu na celkové souvislosti a dodržování správné míry a abychom vyvíjeli odpovídající struktury řádu a regulace. Není na individuální libovůli, zda se schopnosti a možnosti využijí zodpovědně, nebo nezodpovědně. Kdo se zde proviní, proviní se vůči sobě i proti druhým v uskutečňování lidství ve zodpovědné svobodě.

24 K tomu srov. Walter EUCKEN, Grundsätze der Wirtschaftspolitik, 7. vydání, Tübingen, 2008; Alfred MÜLLER-ARMACK, Genealogie der Sozialen Marktwirtschaft, Bern, 1974; Robert SCHUMANN, Wertgrundlagen der Sozialen Marktwirtschaft: Eine genealogische Analyse ihrer Inhalte, Marburg, 2007.

25 Srov. ke „globalizaci“ např. B. Joseph STIGLITZ, Die Chancen der Globalisierung (Making Globalization Work), München, 2006; Ralf ELM, Ethik, Politik und Kulturen im Globalisierungsprozess. Eine interdisziplinäre Zusammenführung, Bochum, 2003; Ulrich BECK, Weltrisikogesellschaft. Auf der Suche nach der verlorenen Sicherheit, Frankfurt/M, 2007; Tomáš SEDLÁČEK, Die Ökonomie von Gut und Böse (Ekonomie dobra a zla, Praha, 2009), München, 2012. 


\section{5. „Kulturní paradigma 21. století“?}

Je „globalizace“ kulturním paradigmatem 21. století? „Globalizace“v nastíněných dimenzích je každopádně dominující společenskou hlubokou přeměnou a její kultivace je epochální výzvou. Abychom však mohli hovořit o kulturním paradigmatu, bylo by ještě zapotřebí mít inspirující, mobilizující a integrující „vzor“, „vizi“ srovnatelnou se středověkou vůdčí představou „ř́du“ jako kontrastní vize $\mathrm{k}$ chaosu nebo $\mathrm{k}$ novověké vůdčí představě „osvobození“ jako kontrastní vize $\mathrm{k}$ bezmoci, nouzi a cizímu rozhodování shora, a dále vyznačení dosažitelných dílčích cílů. Nové kulturní paradigma 21. století bude mít spíše co do činění se srůstáním v „jeden svět", se vztahy místo ovládání. To však není možné vykonstruovat, vyžadovat nebo předepsat, to pravděpodobně potřebuje ještě bolestné procesy zrání a objasňování.

Jaký př́nos je možné očekávat od církve a od teologie? Pastorální konstituce artikuluje - biblicky inspirována - velmi optimistická očekávání srůstu do jednoho solidárního světa. ${ }^{26}$ To by však bylo dost mlhavé a nadnesené, kdybychom si neuvědomili, že biblické poselství je „nasměrování v dějinách" a při inkarnaci a inkulturaci biblického poselství je třeba počítat s dlouhými cestami, kroky zpět, bludnými cestami i zacházkami. Zbožní, eticky smýšlející lidé a hnutí by často chtěli dosáhnout velkých cílů bez ohledu na nezbytné cesty, prostředky, předpoklady a časovou náročnost a reagují pak na nevyhnutelné frustrace depresivně a agresivně. Biblická naděje je však střízlivá, potřebuje trpělivost a vytrvalost. Krátká dílčí bilance globální situace ukazuje, že v současné době existují celosvětová propojení a nikoliv bezvýznamné, i když ještě slabé globální instituce, jako je OSN a její dílčí organizace pro bezpečí, zdraví, sociální sféru, životní prostředí, uprchlíky, děti atd. Existuje značná celosvětová solidarita při zemětřesení, povodních a katastrofách hladomoru, omezeně i vůči uprchlíkům. Celkově je však globalizace ještě pod brutálním vlivem ekonomiky, potenciály konfliktů a otevřené konflikty přibývají, do značné míry panuje pěstní právo a právo silnějšího.

Kde jsou naše církve? ${ }^{27}$ Církve a křestané byli a jsou - díky Bohu - příkladem v oblasti sociální a charitativní pomoci. To je důležitý úsek „žitého sociálního učení“. Sociální pomoc v nouzi a lidsky důstojné utváření společnosti jsou ovšem nezbytné paralelně. Sociální nouze bude ve světě, jaký je, existovat vždy, avšak rozsah a formy sociální nouze souvisejí s konkrétním utvářením společnosti. Dobré utváření společnosti může preventivně snížit vznik nouze, na druhé straně bychom však se sociální pomocí v nouzi naprosto nevystačili, kdyby špatně nastavená společenská situace nouzi lavinovitě vytvářela. Při socio-ekonomicky utvářené společnosti má naše církev - důvody pro to byly uvedeny výše - málo kompetence a relevance. Nepomohlo by, kdybychom kompenzovali tento deficit obzvlášt ostrými morálními apely a imperativy, pranýřováním pochybení, výzvami ke vzdání se něčeho a ohlašováním budoucího soudu a apokalyps. $\mathrm{K}$ tomu máme dlouhou církevní tradici, zřejmě i s cílem ovládání a disciplíny. $\mathrm{K}$ tomu však už nikdo nepotřebuje církev, to nyní obstarají občanská společenská hnutí. Uvidíme, jak a jak dlouho budou působit.

26 Srov. GS 26-32, 40-45.

27 O přehled aktuálních „znamení doby“ se snaží sborník Christoph BÖTTIGHEIMER - Florian BRUCKMANN (ed.), Glaubensverantwortung im Horizont der „Zeichen der Zeit“ (Quaestiones disputatae sv. 248), Freiburg im Breisgau: Herder, 2012; Helmut RENÖCKL, Kulturell-politische und religiöse Umbrüche in (Mittel-)Europa, in: Glaubensverantwortung im Horizont der "Zeichen der Zeit", ed. Christoph BÖTTIGHEIMER - Florian BRUCKMANN, s. 29-50. Srov. také Hans-Joachim HÖHN, Postsäkular. Gesellschaft im Umbruch - Religion im Wandel, Paderborn, 2007. 
Vzhledem $\mathrm{k}$ postmodernímu nedostatku naděje, slabosti $\mathrm{v}$ orientaci a apokalyptickým obavám existuje fundamentální deficit hluboce odůvodněné naděje včetně odpovídající životní orientace. To, že jsou lidé subjektem, je zpochybňováno. Avšak zde jde o jádro biblického poselství. Je třeba připomenout, že papež koncilu Jan XXIII. označil již tehdy četné zastrašovače za „Baalovy proroky“ a současný papež dal své první encyklice název Evangelii gaudium, Radost evangelia. Samozřejmě že nestačí tuto radostnou zvěst jen hlásat, lidé potřebují ve svém životním světě zažít křest’ansky věřící společenství na cestě, v nichž se toto poselství žije, kde mohou zakusit bezpečí a povzbuzení, kde se předává inspirace, odvaha a kompetence ke kormidlování a řízení přes rozbouřené vody epochálních převratů. Stav pastorace v našich středoevropských společnostech však vzbuzuje velké obavy. ${ }^{28}$ Koncilní teolog Karl Rahner poukázal na to, že teologie není nějaká akademická hříčka, ale že je to „reflexe žité víry“, a to platí rovněž pro křestanskou sociální etiku. Jeho bratr Hugo Rahner ve svých studiích o „obrazech církve u apoštolských Otcü“ jasně ukázal, že církev musí být připravena všechny své struktury a formy znovu měnit, aby odpovídaly ústřednímu úkolu sloužit lidem pro život v Božím proudu života. Apoštolští Otcové srovnávají církev s Měsícem. Měsíc nemá své vlastní světlo, má světlo Slunce, kterým je v této metafoře Kristus, aby ho zrcadlil na Zemi, k lidem. Tvary Měsíce se mění a musí se měnit. Důležité je, aby církev, Měsíc, skutečně plnila svou centrální funkci, aby zprostředkovávala lidem oživující světlo Slunce, Krista. ${ }^{29}$ Oto Mádr, vyznavač české církve, jasně vyjádřil v nejvyšším ohrožení ve vězení: „Jen tehdy, jestliže bude církev připravena následovat cestu svého zakladatele do kenosis, do smrtelnosti všech svých sebezajištění, bude mít podíl na síle a dynamice velikonočního vzkříšení.“" ${ }^{30}$

Překlad: Mgr. Marta Rynešová

\title{
Gaudium et spes a kulturní paradigma 21. století
}

\begin{abstract}
Abstrakt
Článek nejprve představuje kulturní paradigma pojednané v pastorální konstituci Gaudium et spes. Poté se věnuje důležitým změnám kulturního paradigmatu v období padesáti let od ukončení koncilu, a to vždy se zřetelem na vztahy mezi "církví" a "světem“. Závěrem se článek zabývá kulturním paradigmatem 21. století a príspěvkem církve a teologie k lidsky dưstojnému uspořádání společnosti.
\end{abstract}

Klíčová slova: Gaudium et spes, kulturní paradigma, církev, svět, globalizace

\section{Kontakt na autora \\ Prof. Dr. Helmut Renöckl}

Johannes Kepler Universität Linz

Technisch-Naturwissenschaftliche Fakultät

Altenberger Straße 69, A-4040 Linz

renoeckl@fim.uni-linz.ac.at

$28 \mathrm{~K}$ tomu srov. dokumentaci př́slušné konference Teologické fakulty Jihočeské univerzity v Českých Budějovicích: Martin WERLEN, Hören auf die, von denen man nichts erwartet, in: Pastoraler Aufbruch oder Selbsterhaltungsbetrieb? Missionarisch Kirche sein, ed. Karl SCHLEMMER - Zdeněk DEMEL, České Budějovice: Teologická fakulta Jihočeské univerzity, 2005, s. 53-59.

29 Hugo RAHNER, Symbole der Kirche. Die Ekklesiologie der Väter, Salzburg, 1964, s. 91-139.

30 Oto MÁDR, Wie Kirche nicht stirbt (Jak církev neumírá), in: Slovo o této době, Praha: Zvon, 1992; Leipzig: St. Benno-Verlag, 1993, s. 30-38. 